\title{
Decision Support System for Surface Irrigation Design
}

\author{
José M. Gonçalves ${ }^{1}$ and Luis S. Pereira, M.ASCE${ }^{2}$
}

\begin{abstract}
The SADREG decision support system was developed to help decision makers in the process of design and selection of farm surface irrigation systems to respond to requirements of modernization of surface irrigation-furrow, basin, and border irrigation. It includes a database, simulation models, user-friendly interfaces, and multicriteria analysis models. SADREG is comprised of two components: design and selection. The first component applies database information, and through several simulation and computational tools, produces a set of design alternatives in agreement with the user options. These alternatives are characterized by several hydraulic, economic, and environmental indicators that allow appropriate selection and ranking. The selection component bases upon multicriteria analysis using composite programming and ELECTRE II ranking models, which support the decision maker to select the best alternative. The decision maker participates in all decision processes through a user-friendly interface that allows expressing design options and priorities. SADREG was tested with data collected from field experiments. In addition to describing the modeling approach, an application to a sector of the Lower Mondego Irrigation Project, Portugal, is presented.
\end{abstract}

DOI: 10.1061/(ASCE)IR.1943-4774.0000004

CE Database subject headings: Irrigation; Economic factors; Environmental issues; Decision support systems; Portugal.

\section{Introduction}

Surface irrigation systems have the largest share in irrigated agriculture all over the world. The performance of surface irrigation systems highly depends upon the design process, which is related to the appropriateness and precision of land leveling, field shape and dimensions, and inflow discharge. Moreover, the irrigation performance also depends on farmer operative decisions, mainly in relation to land leveling maintenance, timeliness and time duration of every irrigation event, and water supply uncertainties (Pereira 1999; Pereira et al. 2002).

The design procedures of farm surface irrigation drastically changed in recent years. The classical ones were based upon empirical rules (Criddle et al. 1956; Wilke and Smerdon 1965). A quasi-rational methodology taking into consideration the main design factors was developed by the Soil Conservation Service. It was based upon the continuity equation and was supported by intensive field observations (SCS 1974, 1979). This methodology was widely applied and adopted in optimization procedures (Reddy and Clyma 1981a,b). It assumes the soil classification in infiltration family types, related with soil texture, and evaluated from infiltrometer observations (Hart et al. 1980). For furrows design, an empirical advance curve was applied relating inflow discharge, slope, length, and infiltration. Other classical methods refer to the volume-balance models using the continuity equation

\footnotetext{
${ }^{1}$ Assistant Professor, Agricultural Engineering Research Center, Institute of Agronomy, Technical Univ. of Lisbon, Portugal. E-mail: jmmg@ mail.esac.pt

${ }^{2}$ Professor and Head, Agricultural Engineering Research Center, Institute of Agronomy, Technical Univ. of Lisbon, Portugal (corresponding author). E-mail: 1spereira@ isa.utl.pt

Note. This manuscript was submitted on February 27, 2008; approved on October 1, 2008; published online on January 22, 2009. Discussion period open until November 1, 2009; separate discussions must be submitted for individual papers. This paper is part of the Journal of Irrigation and Drainage Engineering, Vol. 135, No. 3, June 1, 2009. (CASCE, ISSN 0733-9437/2009/3-343-356/\$25.00.
}

and empirical information, but neglecting the dynamic flow equation. Examples are referred by Walker and Skogerboe (1987), Yu and Singh (1989, 1990), and Clemmens (2007). These types of models also apply to irrigation management when optimizing the performance from advance data observations (Latimer and Reddel 1990; Mailhol et al. 2005; Camacho et al. 1997).

Numerous mathematical computer models for surface irrigation simulation were developed. They originated a new age on design methods, with increased quality of procedures, because they allow the quantification of the integrated effect of main irrigation factors (length, discharge, slope, soil roughness, shape, and infiltration) on performance, thus, enlarging the solution set with higher precision and effectiveness than the traditionally empirical methods. Strelkoff and Katopodes (1977) first presented an application of zero-inertia modeling for border irrigation. Further developments were described for borders, basins, and furrows (Fangemeier and Strelkoff 1978; Clemmens 1979; Elliott et al. 1982), and were followed by furrow surge flow modeling (Oweis and Walker 1990). The kinematics wave and the hydrodynamics model for furrows were later introduced (Walker and Humpherys 1983; Strelkoff and Souza 1984). Computer models for design of basin irrigation include BASCAD (Boonstra and Jurriens 1978) and BASIN (Clemmens et al. 1993), and for border irrigation include the BORDER model (Strelkoff et al. 1996). The models SRFR (Strelkoff 1990) and SIRMOD (Walker 1998) apply to furrows, basin, and border irrigation and adopt various approaches for solving the continuity and momentum equations. Reviews were recently produced by Pereira et al. (2006) and Strelkoff and Clemmens (2007).

In addition to hydraulics simulation models, surface irrigation design requires the application of other type of models such as for irrigation scheduling, land leveling, distribution systems, and cost and environmental analysis. In practice, it is usually difficult to manage data for an interactive application of these models in design when they are not integrated with a common database. The decision support systems (DSSs) methodology creates the framework to explore the synergy between mathematical simulation models, data and user knowledge through its integration 


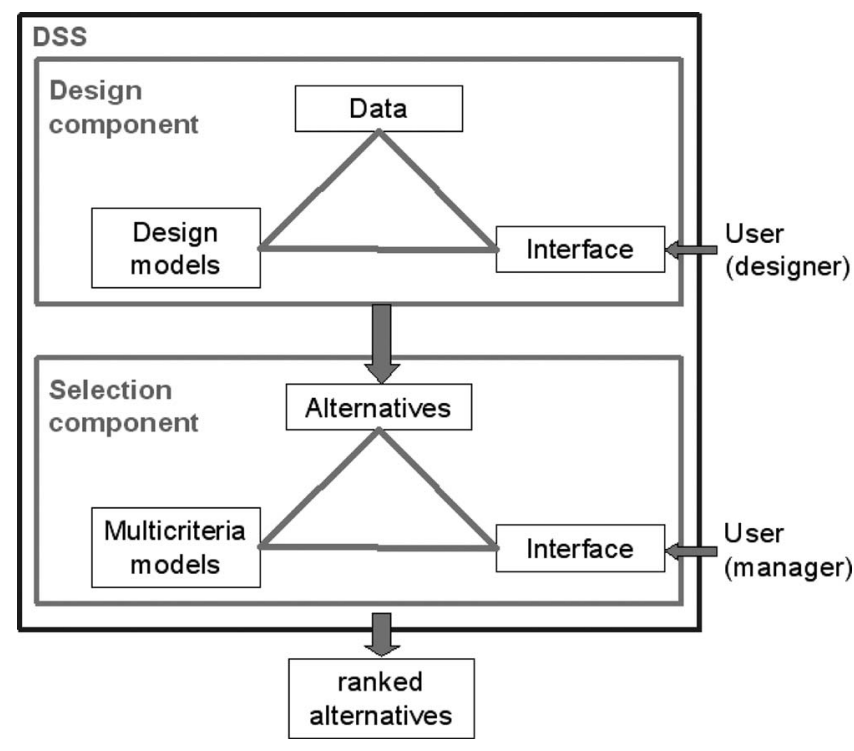

Fig. 1. Conceptual structure of SADREG

aimed to help the decision maker to solve complex problems. The DSS methodology makes handling data of various types easier and effective, and favors the integration of simulation models and their interactive application. It provides for a decision-maker learning process, and through the inclusion of multicriteria analysis, it supports a decision process and related choices. DSSs are often applied to irrigation planning and policy analysis (Bazzani 2005; Riesgo and Gómez-Limón 2006), as well as to performance assessment and water demand and delivery simulation (Raju and Duckstein 2002; Rao et al. 2004; Oad et al. 2006; Raju et al. 2006; Gonçalves et al. 2007). However, few applications are developed for surface irrigation (Gonçalves and Pereira 1999; McClymont 1999; Hornbuckle et al. 2005).

The variety of aspects influencing irrigation performance (Burt et al. 1997; Pereira et al. 2002) makes the design process quite complex, and a multicriteria analysis approach is then advantageous. Alternative design solutions may be ranked following various objectives and criteria, such as improving the irrigation performance, achieving water saving, attaining high water productivity, or maximizing farm incomes. Using a DSS and multicriteria analysis is helpful to produce appropriate comparisons among alternative design solutions and to perform a trade-off analysis (Roy and Bouyssou 1993; Pomerol and Romero 2000). In this line, the DSS SADREG for surface irrigation design was developed and tested in a variety of applications. The objective of this paper is to present SADREG and the approaches supporting its development, including results of its application to one irrigation sector of the Lower Mondego Irrigation Project (Portugal).

\section{Architecture of the DSS SADREG}

SADREG is a DSS designed to assist designers and managers in the process of design and planning improvements in farm surface irrigation systems-furrow, basin, and border irrigation. It includes a database, simulation models, user-friendly interfaces, and multicriteria analysis models.

SADREG is comprised of two components: design and selection (Fig. 1). The first component applies database information and produces a set of design alternatives in agreement with the

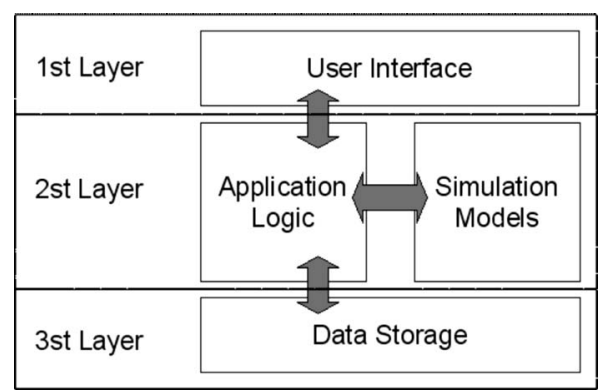

Fig. 2. DSS architecture by layers

user options. These alternatives are characterized by various hydraulic, economic, and environmental indicators that allow appropriate selection and ranking. The selection component is based upon multicriteria analysis for ranking the alternatives, thus, supporting the decision maker to select the best design solution. The decision maker participates in all decision processes through interface dialogue structures that allow expressing design and management options and priorities.

SADREG is a client-server application whose software follows a high level architecture by layers (Fig. 2). The first layer concerns the user interface; the second refers to the application logic, which controls the interactive use of the simulation models when creating the design alternatives. The database constitutes the third layer and is built with Open Data Base Connectivity (ODBC) technology applying Microsoft Access. Microsoft Visual Basic 6 is used to develop the graphical interface and Microsoft Visual $\mathrm{C}++6$ is used in the computation modules. The dialogue interface structures are user friendly to facilitate the user data input and validation.

The databases refer to data of various natures, some constituting input data required for computations; others are created through successive computations/simulations (Fig. 3). The main components are:

1. General field data, relative to soils and environment (e.g., soil infiltration, soil water holding capacity, soil salinity, groundwater depth, and climate), crops (planting date, yields, yield function parameters), equipment characteristics and costs, operational costs and benefits;

2. Field data characterizing the field under design: length,

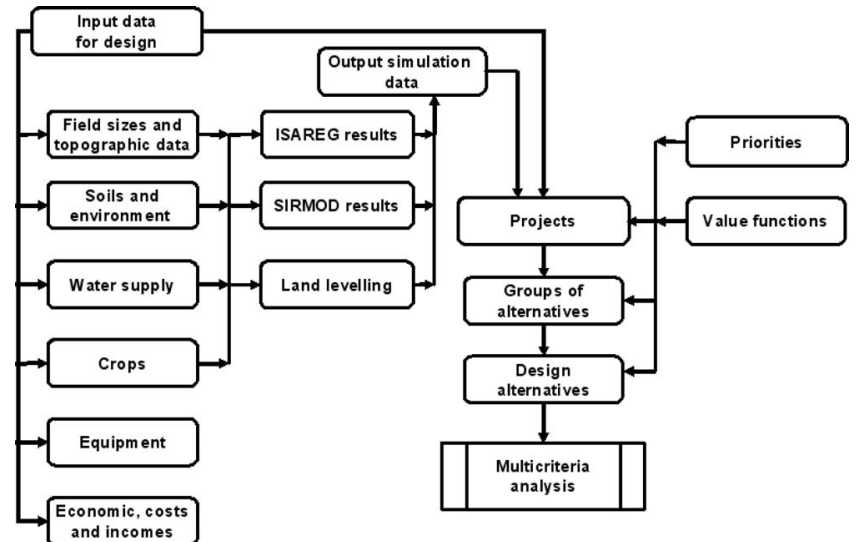

Fig. 3. Data base components in relation to respective sources and uses in the design process 


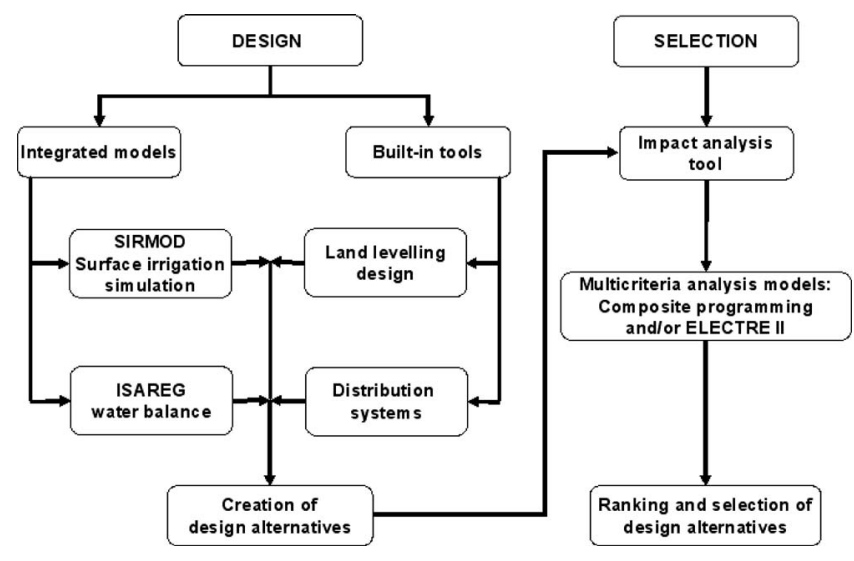

Fig. 4. Model base components

width, slopes, surveying data, and characteristics of the respective water supply;

3. Data created through simulations performed with the models SIRMOD for surface irrigation simulation (Walker 1998) and ISAREG for irrigation scheduling simulation (Pereira et al. 2003);

4. Project data, referring to data characterizing the alternatives; and

5. Selection data, referring to the value functions and decision priorities.

SADREG includes various computational models and tools (Fig. 4). The simulation of the surface irrigation systemsfurrows, borders, and basins - is performed by the surface irrigation simulation model SIRMOD (Walker 1998), which is integrated within SADREG. The water balance simulation to define the application depths and timings is performed by the ISAREG model (Pereira et al. 2003), which is linked (loose integration) with SADREG and explored interactively. Calculations relative to land leveling and farm water distribution systems are performed through specific built-in tools. These computational tools provide for the characterization of each design alternative, including a complete set of performance indicators. The resulting data are later handled by an impact analysis tool, so creating all data required for multicriteria analysis. The impact analysis tool performs calculations relative to crop yields and related incomes (benefits), costs, and environmental impacts as described later. Ranking and selection of alternatives are performed with composite programming and the ELECTRE II models (Roy and Bouyssou 1993; Pomerol and Romero 2000).

The SADREG applications scope is comprised of (a) a single field analysis relative to alternative design options for furrow, basin, or border irrigation, considering several decision variables such as field slopes, farm water distribution systems and runoff reuse; and (b) an irrigation sector analysis, when a spatially distributed database relative to the farm systems is available. In this case, the alternatives are assessed jointly with modernization options relative to the conveyance and distribution network. It applies to farm land parcels or fields, of rectangular shape, with a well known geographical location, supplied by a hydrant, a gate, or other facility at its upstream end. A field is characterized by its length and width, slope and land surface unevenness, soil infiltration and soil water retention characteristics, both assumed as spatially uniform for design purposes. Large fields may be subdivided into units, which are field fractions supplied by a single outlet, all having the same width, length, and slope. In addition, subunits may be considered when the water available or management constraints impose that a unit is not fully irrigated simultaneously. In order to design the upstream water distribution, the field characterization requires definition on which direction, OX or OY, the distribution system should be located. Hydrants or farm gates supply the water to the field with known discharge and hydraulic head. In large fields, farm canals or pipes supplied by those hydrants or gates may deliver the water to the upstream distribution system through various outlets, equaling the number of units. In small fields, generally only one unit is considered and the outlet coincides with the hydrant or gate.

A hierarchical approach is used to develop the design alternatives (Fig. 5). Data referring to field characteristics common to all alternatives are organized in a workspace. Included in the field workspace are the projects whose data structure is aimed at developing a set of design alternatives relative to:

1. The crop type (e.g., cereals versus row crops);

2. The irrigation method;

3. The land leveling solution, to be defined in agreement with the irrigation method, field longitudinal and cross-slopes, and the selected upstream distribution side;

4. The water supply conditions that influence, together with the irrigation method, the Options relative to the number and size of units and the outlet's discharge; and

5. Costs and other financial parameters.

The design alternatives are clustered into groups included in a project and relative to:

1. The upstream distribution system, which depends upon the selected irrigation method and equipment available; and

2. The tail end management system, which also depends upon the irrigation method and the equipment available.

The alternatives constitute complete design solutions. Within a group, they are differentiated by the operative parameters: the inflow rate per unit width of land being irrigated or per furrow, and the number of subunits.

\section{Irrigation System Design}

\section{Decision Variables}

The surface irrigation methods considered are level basin irrigation, with flat or furrowed soil surface, graded basins, borders, and graded furrows (Table 1). Level furrows are treated as furrowed level basins. For cereals, furrows of corrugated type may be considered.

The decision variables relative to the irrigation design process are described in Table 2. They depend upon the irrigation method since it influences the field layout and land leveling, the water supply and distribution, the tail water management, and the farm irrigation management.

\section{Land Leveling}

When starting a project, the user must select the irrigation method, the upstream distribution side, and carry out a land leveling simulation adopting cross and longitudinal field slopes appropriate to the considered irrigation method and the actual field slopes. The land leveling simulation tool computes the cut and fill volumes required to change from the actual elevations $z_{a}(x, y)$ into the target elevations 


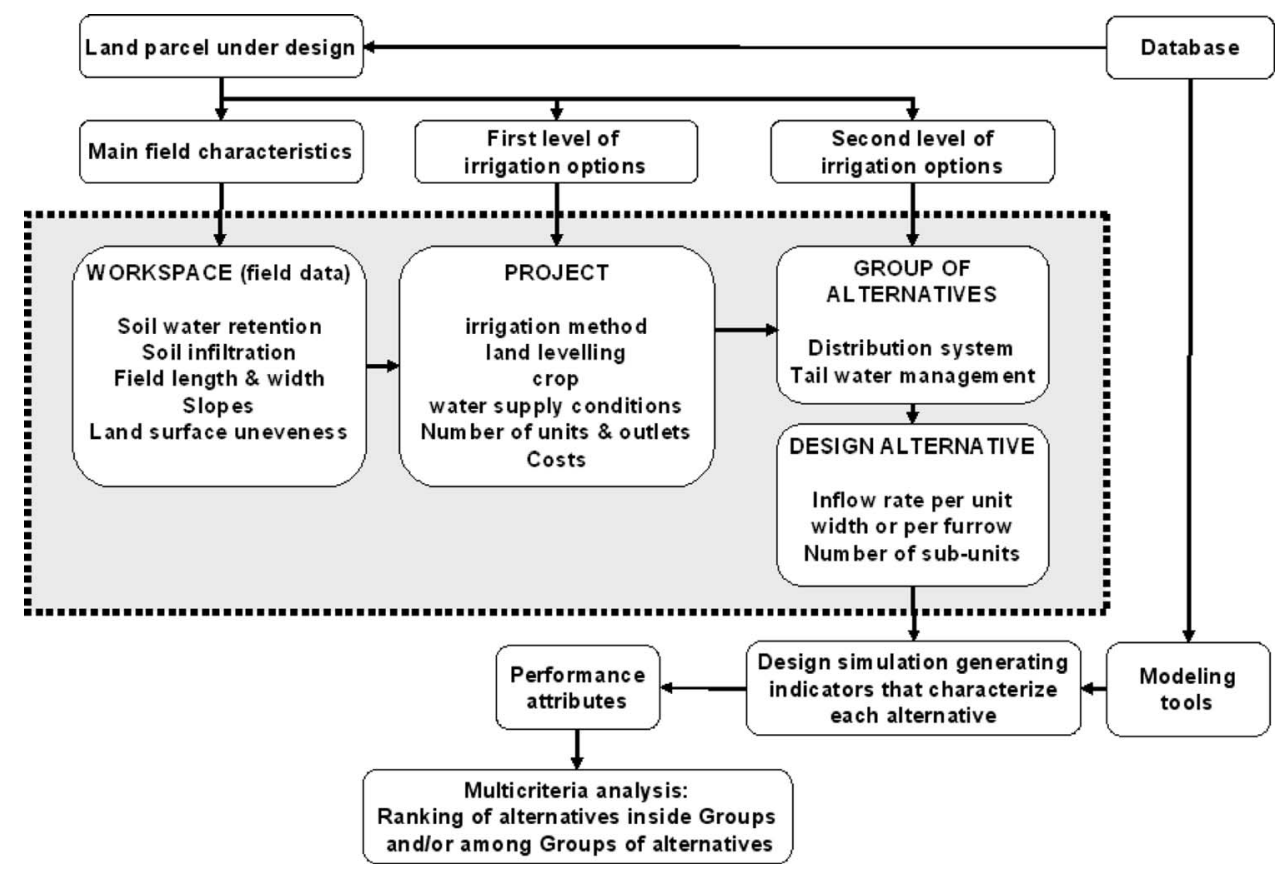

Fig. 5. Scheme of the creation of field design alternatives using a multilevel approach for design and application of multicriteria ranking and selection

$$
z(x, y)=z_{0}+S_{x}\left(x-x_{0}\right)+S_{y}\left(y-y_{0}\right)
$$

where $x_{0}, y_{0}, z_{0}=$ coordinates of the center of gravity of the field $(\mathrm{m})$; and $S_{x}$ and $S_{y}=$ longitudinal and cross-slopes $\left(\mathrm{m} \mathrm{m}^{-1}\right)$ along the OX and OY axis, respectively (Dedrick et al. 2007). The plan position (value of $z_{0}$ ) is iteratively changed until the cut to fill ratio becomes $>1.0$ and $<1.2$ (Fig. 6). Results include the cut and fill depths and volumes, and related costs.

\section{Infiltration and SIRMOD Application}

The modified Kostiakov equation is applied in the SIRMOD model (Walker 1998) to compute soil infiltration. For continuous flow, it takes the form

$$
Z=K \cdot \tau^{a}+f_{0} \cdot \tau
$$

where $Z=$ cumulative infiltration $\left(\mathrm{m}^{3} \mathrm{~m}^{-1}\right) ; \tau=$ infiltration time (min); $K\left(\mathrm{~m}^{3} \mathrm{~m}^{-1} \mathrm{~min}^{-\mathrm{a}}\right)$ and a (dimensionless) are empirically adjusted parameters; and $f_{0}=$ basic infiltration rate $\left(\mathrm{m}^{3} \mathrm{~min}^{-1} \mathrm{~m}^{-1}\right)$. For surge flow, the procedure developed by Walker and Humpherys (1983) is adopted:

- For infiltration on dry soil (first wetting), Eq. (2) is applied;
- For infiltration on wetted soil (third and successive wettings) the parameters $a, K$, and $f_{0}$ in Eq. (2) are modified into $K_{s}, a_{s}$, and $f_{0 s}$, thus, producing the surge infiltration equation; and

- For infiltration during the second wetting, a transition curve is applied.

This transition equation balances the effects represented by the equations for dry and wetted soil (Walker 1998; Horst et al. 2007)

$$
Z=\left[K+\left(K-K_{s}\right) \mathrm{FP}\right]^{\tau\left[a+\left(a-a_{s}\right) \mathrm{FP}\right]}+\left[f_{0}+\left(f_{0}-f_{0 s}\right) \mathrm{FP}\right] \tau
$$

where FP (dimensionless) = distance-based factor computed from the advance distances $x_{i-2}$ and $x_{i-1}$ relative to the surge cycles $i-2$ and $i-1$.

To characterize each field, SADREG includes a set of infiltration data concerning families of infiltration curves for continuous and surge flow, typical of seasonal irrigation events (first, second, and later irrigations) under flat soil infiltration conditions. Field observations of infiltration can be added to this set of infiltration curves and be used for the respective design case study. When no field infiltration data are available, the user selects the curves to

\begin{tabular}{|c|c|c|c|c|}
\hline $\begin{array}{l}\text { Irrigation } \\
\text { method }\end{array}$ & $\begin{array}{l}\text { Soil surface } \\
\text { condition }\end{array}$ & Field slopes & Field inflow conditions & Tail end conditions \\
\hline Level basin & Flat or furrowed & Zero in all directions & $\begin{array}{l}\text { Point inflow at one or various locations, } \\
\text { or to individual furrows }\end{array}$ & Diked \\
\hline $\begin{array}{l}\text { Graded basin } \\
\text { and borders }\end{array}$ & Flat or furrowed & $\begin{array}{l}\text { Longitudinal slope } \neq 0 \\
\text { and cross-slope }=0\end{array}$ & $\begin{array}{l}\text { Point inflow at one or various locations, } \\
\text { or to individual furrows }\end{array}$ & $\begin{array}{l}\text { Diked for basins } \\
\text { and open for borders }\end{array}$ \\
\hline Graded furrows & Furrowed & $\begin{array}{l}\text { Longitudinal } \\
\text { and cross-slope } \neq 0\end{array}$ & Inflow to individual furrows & Open or diked \\
\hline
\end{tabular}
be used considering the available soil data. To adjust the param-

Table 1. Irrigation Methods 
Table 2. Design and Management Decision Variables

\begin{tabular}{|c|c|c|}
\hline & & Decision variables \\
\hline \multirow[t]{16}{*}{ Design } & Field layout and land leveling & - Upstream distribution side (OX or OY) \\
\hline & & - Field length (FL) and field width (FW) \\
\hline & & - Cross-slope $\left(S_{\mathrm{oC}}\right)$ \\
\hline & & - Longitudinal slope $\left(S_{\mathrm{o}}\right)$ \\
\hline & Water supply conditions & - Number of outlets $\left(N_{\mathrm{o}}\right)$ \\
\hline & & - Number of units $\left(N_{u}\right)$ \\
\hline & & - Total field supply discharge $\left(Q_{F}\right)$ \\
\hline & & - Outlet discharge $\left(Q_{\mathrm{o}}\right)$ and hydraulic head $\left(H_{\mathrm{o}}\right)$ \\
\hline & & - Field delivery time duration $\left(t_{F}\right)$ \\
\hline & Farm distribution system & - Continuous and constant inflow rate for basins and borders \\
\hline & & $\begin{array}{l}\text { - Continuous or surge flow with automatic or manual surge valves } \\
\text { for graded furrows }\end{array}$ \\
\hline & & $\begin{array}{l}\text { - Lined or unlined canal, or gated pipes, or layflat tubing for } \\
\text { all methods }\end{array}$ \\
\hline & Tailwater management & - No tail water runoff for basins and diked furrows \\
\hline & & - Open without tail water reuse \\
\hline & & - Open and reuse by pumping to the upstream end \\
\hline & & - Open and gravity reuse on other fields \\
\hline \multirow[t]{5}{*}{ Management } & Irrigation scheduling & - Irrigation timing \\
\hline & & - Required application depths \\
\hline & & - Application time $\left(t_{\mathrm{ap}}\right)$ \\
\hline & Distribution system operation & - Inflow rate per unit width or per furrow $\left(q_{\mathrm{o}}\right)$ \\
\hline & & - Number of subunits $\left(n_{s}\right)$ \\
\hline
\end{tabular}

eters for furrow irrigation, the procedure proposed by SCS (1979) and Walker (1989) is applied. It is based on the average wetted perimeter (WP) $(\mathrm{m})$ and the adjusting coefficient $\left(C_{\text {adj }}\right)$. WP is given by

$$
\mathrm{WP}=0.265\left(\frac{q \cdot n}{\sqrt{S_{0}}}\right)^{0.425}+0.227
$$

where $q=$ furrow inflow discharge $\left(1 \mathrm{~s}^{-1}\right) ; n=$ Manning's rough-

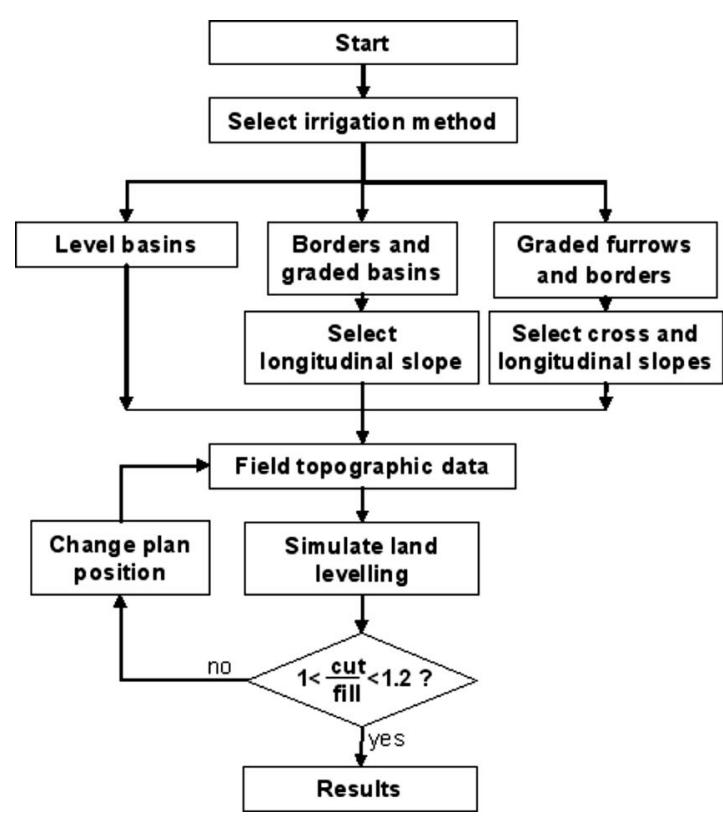

Fig. 6. Flowchart of the application of the land leveling simulation tool ness coefficient $\left(\mathrm{s} \mathrm{m}^{-1 / 3}\right)$; and $S_{o}=$ furrow longitudinal slope $\left(\mathrm{m} \mathrm{m}^{-1}\right)$. The adjusting coefficient $C_{\mathrm{adj}}$ is estimated as

$$
C_{\text {adj }}=0.5, \ldots \text { if } \frac{\mathrm{WP}}{\mathrm{FS}}<0.5 \text { else } C_{\mathrm{adj}}=\frac{\mathrm{WP}}{\mathrm{FS}}
$$

where FS $(\mathrm{m})=$ furrow spacing. The parameters $K$ and $f_{0}$ [Eq. (2)] and the surge-flow infiltration parameters are adjusted as

$$
\begin{aligned}
& K_{\text {adj }}=C_{\text {adj }} \cdot K \\
& f_{\text {0adj }}=C_{\text {adj }} \cdot f_{0}
\end{aligned}
$$

The SIRMOD model is applied for several input conditions that cover all situations relative to the user options to create alternatives. The continuous input variables consist of: field length $(\mathrm{FL}, \mathrm{m})$, required application depth $\left(Z_{\mathrm{req}}, \mathrm{mm}\right)$, field longitudinal slope $\left(S_{0}\right)$, Manning's hydraulics roughness coefficient $(n)$, furrow spacing (FS), and inflow rate per unit width or per furrow $\left(q, 1 \mathrm{~s}^{-1}\right)$. The discrete input variables required are: inflow regime (continuous or surge flow), tail end management (open, diked, or open with reuse), cross-section shape (flat or various furrow types), and parameters of the infiltration equation.

Any run of SIRMOD produces output data including: application, advance, and recession times; infiltration depths; runoff and percolation volumes; and performance indicators, mainly those defined in Table 3 (Walker and Skogerboe 1987; Pereira and Trout 1999).

The SIRMOD model is used iteratively for a given alternative to search the irrigation parameters referred to above that comply with the application of the required irrigation water depth $Z_{\text {req }}$ $(\mathrm{mm})$. This one is computed by running interactively the model ISAREG for the considered crop, soil, and climate. In SIRMOD simulation, an appropriate inflow rate $q\left(q_{\min }<q<q_{\max }, 1 \mathrm{~s}^{-1} \mathrm{~m}^{-1}\right)$ is iteratively selected using increments $\Delta q=0.1 \mathrm{l} \mathrm{s}^{-1}$. However, it may happen that the model does not converge and it becomes 
Table 3. Performance Indicators (Units in \%)

\begin{tabular}{|c|c|}
\hline Indicator & Definition \\
\hline Application efficiency & $E_{a}= \begin{cases}\frac{Z_{\mathrm{req}}}{D} \times 100 & Z_{\mathrm{lq}}>Z_{\mathrm{req}} \\
\frac{Z_{\mathrm{req}}}{D} \times 100 & Z_{\mathrm{lq}}<Z_{\mathrm{req}}\end{cases}$ \\
\hline Distribution uniformity & $\mathrm{DU}=\frac{Z_{\mathrm{lq}}}{Z_{\mathrm{avg}}} \times 100$ \\
\hline Water requirement efficiency & $E_{r}=\frac{Z_{\mathrm{avg}(\mathrm{root})}}{Z_{\mathrm{req}}} \times 100$ \\
\hline Infiltration efficiency & $\mathrm{IE}=\frac{Z_{\mathrm{avg}}}{D} \times 100$ \\
\hline Tail water runoff ratio & $\mathrm{TWR}=\frac{Z_{\mathrm{run}}}{D} \times 100$ \\
\hline Deep percolation ratio & $\mathrm{DPR}=\frac{Z_{\mathrm{dp}}}{D} \times 100$ \\
\hline \multicolumn{2}{|c|}{$\begin{array}{l}\text { Note: } Z_{\text {req }}=\text { the average water depth }(\mathrm{mm}) \text { required to refill the root zone } \\
\text { in the lower quarter of the field. } D=\text { average water depth applied to the } \\
\text { irrigated area }(\mathrm{mm}) . Z_{\mathrm{lq}}=\text { average depth of water infiltrated in the lowe } \\
\text { quarter of the field }(\mathrm{mm}) . Z_{\text {avg }}=\text { average depth of water infiltrated in the } \\
\text { whole irrigated area }(\mathrm{mm}) . Z_{\text {avg(root }}=\text { average depth of water infiltratec } \\
\text { stored in the root zone }(\mathrm{mm}) . Z_{\text {run }}=\text { depth of water that runs off at the tai } \\
\text { end of the field }(\mathrm{mm}) . Z_{\mathrm{dp}}=\text { depth of water that percolates below the roo } \\
\text { zone }(\mathrm{mm}) \text {. }\end{array}$} \\
\hline
\end{tabular}

necessary to have a successful simulation trying different combinations of internal simulation parameters (Walker 1998): time step (1-2.5 $\mathrm{min})$, space step $(1-25 \mathrm{~m}$, according to the field length), time weight factor $(0.60-0.65)$, space weight factor (0.50-0.65), and type of hydraulics simulation model (full hydrodynamic or zero inertia). When an inflow rate $q$ is found, a new iteration starts to compute the time $t_{\text {ap }}(\mathrm{min})$ required to apply the water depth $Z_{\text {req. }}$. This is performed by maximizing the water requirement efficiency (Table 3), which should become close to $100 \%$. Results are then saved in the database to be further applied to other alternatives. The results for intermediate values for each of the continuous input variables are calculated by interpolation between those stored in the database instead of running the model several times.

\section{Generation of Alternatives}

The procedure to build up and characterize design alternatives for a given field is performed through the following sequential steps:

1. Selection of the irrigation method: level basin (flat or furrowed), graded basins or border, or graded furrows; for furrows, selection includes the cross-section type and the furrow spacing;

2. Definition of the field side, along the axis OX or OY, where the upstream distribution facilities will be located;

3. Land leveling simulation, then choosing the field slopes more appropriate to the irrigation method, and the actual field topography;

4. Selection of the inflow regime for graded furrows: continuous or surge flow. The surge-flow irrigation management follows the one-fourth length rule for the advance phase, i.e.,

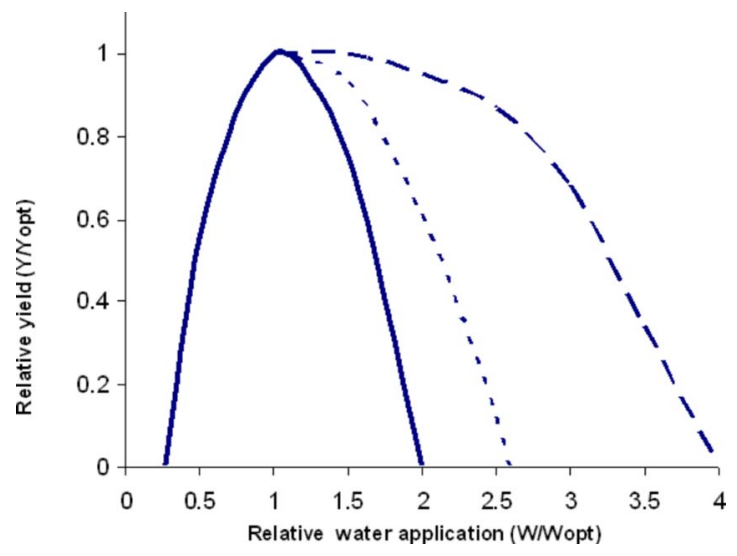

Fig. 7. Irrigation water-yield functions; examples of quadratic equations with different descending branches for a crop susceptible to excess water in a poorly drained soil (-), for a susceptible crop in a drained soil (- - -), and for a nonsusceptible crop in a well drained soil (-)

with increased duration of successive cycles; after the advance is completed, a continuous flow with half-inflow rate applied to the full unit is adopted. For basin and borders, only a continuous inflow rate is considered;

5. Definition of the number of outlets and field units;

6. Selection of the water distribution system among gated pipe, lay-flat tubing, earth canal, or lined canal; when the surgeflow option is selected, the respective control system may be either manual or automatically operated;

7. Selection of a tail water management option for borders and furrows: they may be diked, i.e., closed at the tail end, or open. When open, the tail end runoff may be reused by pumping to the upstream end, reused by gravity in downstream fields, or not reused. Basins are diked; and

8. Estimation of an appropriate crop irrigation scheduling, thus, the required application depths and timings. With this purpose, the ISAREG model is used interactively with SIRMOD for searching the application depths appropriate to the irrigation method.

\section{Impact Evaluation}

The cost analysis considers the investment and the operation and maintenance (O\&M) costs (Mjeld et al. 1990; Solomon et al. 2007). The investment cost refers to the farm distribution system equipment and the initial land leveling. The net present value of the investment cost is calculated on a yearly basis using a capital recovery factor that is a function of the annual interest rate and the lifetime of the components (see the Appendix). The annual O\&M costs include the land leveling maintenance, the distribution system operation and maintenance, and the reuse pumping costs. The database shall include the duration times relative to all irrigation tasks depending upon the irrigation method and the equipment used (see the Appendix). Both investment and O\&M costs vary among the alternatives.

The production costs not referring to irrigation (e.g., fertilization, cultivation, and harvesting) do not differ among alternatives and do not interfere on ranking and selection of alternatives. Thus, they are not included in the cost analysis.

A water-yield function is used to estimate the crop yield from 


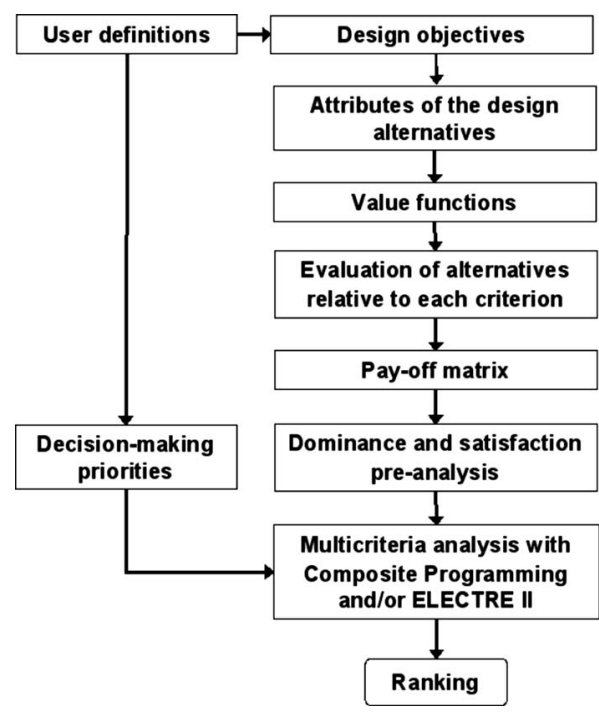

Fig. 8. Scheme of application of the multicriteria methodology

the computed total water use during the irrigation season. A quadratic function (Fig. 7) is adopted to calculate the relative yield $\left(Y / Y_{\text {opt }}\right)$ from the relative water application $\left(W / W_{\text {opt }}\right)$ (Solomon 1984)

$$
\begin{aligned}
Y / Y_{\mathrm{opt}}= & k_{0}+k_{1} \cdot\left(W / W_{\mathrm{opt}}\right)+k_{2} \cdot\left(W / W_{\mathrm{opt}}\right)^{2}+k_{3} \cdot\left(W / W_{\mathrm{opt}}\right)^{3} \\
& +k_{4} \cdot\left(W / W_{\mathrm{opt}}\right)^{4}
\end{aligned}
$$

where $W=$ actual water available for crop evapotranspiration during the irrigation season $(\mathrm{mm}) ; W_{\mathrm{opt}}=$ seasonal water required for achieving maximum crop yield (mm); $Y$ and $Y_{\mathrm{opt}}=$ crop yields $\left(\mathrm{kg} \mathrm{ha}^{-1}\right)$ corresponding to $W$ and $W_{\mathrm{opt}}$, respectively; and $k_{i}(i$ $=1, \ldots, 4)=$ empirical coefficients typical for the crop, and environmental and agronomical conditions under consideration. The decreasing branch of this function is related to soil drainage conditions and excess water impacts on yields. To consider these effects, the user should adjust to the local conditions the descending branch of the quadratic function, as indicated in Fig. 8 where three types of descending branches are presented.

The environmental attributes considered for selection of the design alternatives are:

1. The total irrigation water use during the crop season;

2. The nonreused runoff volume, that represents a nonconsumed and nonbeneficial fraction of water use and is an indicator for potential degradation of surface waters;

3. The deep percolation volume, which represents also a nonconsumed and nonbeneficial fraction of water use and is an indicator for potential degradation of ground waters;

4. The potential land leveling impacts on the soil quality; and

5. The potential for soil erosion.

The total water use, runoff, and deep percolation volumes are calculated with SIRMOD for every single event of the irrigation
Table 5. Objectives and Attributes for Design Selection

\begin{tabular}{lll}
\hline Objectives & Alternative attributes & Units \\
\hline Maximizing benefits & $\begin{array}{l}\text { 1. Yield value } \\
\text { Minimizing costs }\end{array}$ & $\begin{array}{l}\text { 2. Investment cost } \\
\text { 3. Operation and maintenance cost } \\
€ / \text { year } \\
€ / \text { year } \\
\mathrm{m}^{3} / \text { year }\end{array}$ \\
$\begin{array}{l}\text { Minimizing water } \\
\text { degradation and } \\
\text { the nonbeneficial }\end{array}$ & $\begin{array}{l}\text { 5. Runoff } \\
\text { water use }\end{array}$ & $\mathrm{m}^{3} /$ year \\
$\begin{array}{l}\text { Maximizing soil } \\
\text { conservation }\end{array}$ & $\begin{array}{l}\text { 6. Average land leveling } \\
\text { cutting depth }\end{array}$ & $\mathrm{cm}$ \\
& $\begin{array}{l}\text { 7. Erosion index } \\
\text { Index }\end{array}$ \\
\hline
\end{tabular}

season. The seasonal values are obtained by summing up these results. The attribute relative to land leveling impacts is expressed by the average cut depth because the smaller are the cut depths, the lower are the impacts on soil quality.

The potential soil erosion attribute is a qualitative index, EI, which takes values 1-9 in an ascending scale of risk of soil erosion due to the applied irrigation water. EI is an empirical function of the inflow rate $q$ per unit width or per furrow, the longitudinal slope $S_{\mathrm{o}}$, and the soil type considering the empirical concept of maximum nonerosive inflow rate as proposed by Criddle et al. (1956). For furrows in a silt-loam soil, EI values relative to single events are given in Table 4 as a function of the product $q S_{\mathrm{o}}$, where $q$ is in $1 \mathrm{~s}^{-1}$ and $S_{\mathrm{o}}$ is in percentage. For different soil types, these scale values should change similarly to the maximum nonerosive inflow rate. The seasonal EI is the geometric average of the single event values.

\section{Multicriteria Analysis}

The selection of the best irrigation design alternative is a multiple objective problem whose rational solution requires multicriteria analysis. This methodology integrates different types of attributes on a trade-off analysis, allowing the comparison between environmental and economic criteria (Pomerol and Romero 2000). Multicriteria analysis supports a better understanding of the irrigation impacts while enabling us to achieve a satisfactory compromise between adversative decision-maker objectives.

The process starts with the definition of the design objectives and related attributes (Fig. 8). These attributes are then transformed into criteria through user-defined value or utility functions [Eqs. (9) and (10) presented below]. The alternatives and respective criteria are tabled in a payoff matrix, which synthesizes the more relevant data for the selection analysis. A first screen of the alternatives may be done prior to the application of multicriteria using a dominance and satisfaction preanalysis.

A set of design objectives and correspondent attributes are presented in Table 5. The decision criteria refer to:

1. Economic criteria relative to the yield value, the initial investment cost, and the operation and maintenance costs; and

Table 4. Potential Erosion Index EI for Furrows in a Silt-Loam Soil

\begin{tabular}{lccccccccc}
\hline$q S_{\mathrm{o}}$ & & & & & & & & & \\
$1 \mathrm{~s}^{-1} \%$ & $<0.30$ & $0.3-0.5$ & $0.5-0.62$ & $0.62-0.75$ & $0.75-0.87$ & $0.87-1.0$ & $1.0-1.25$ & $1.25-1.5$ & $>1.5$ \\
\hline EI & 1 & 2 & 3 & 4 & 5 & 6 & 7 \\
\hline
\end{tabular}




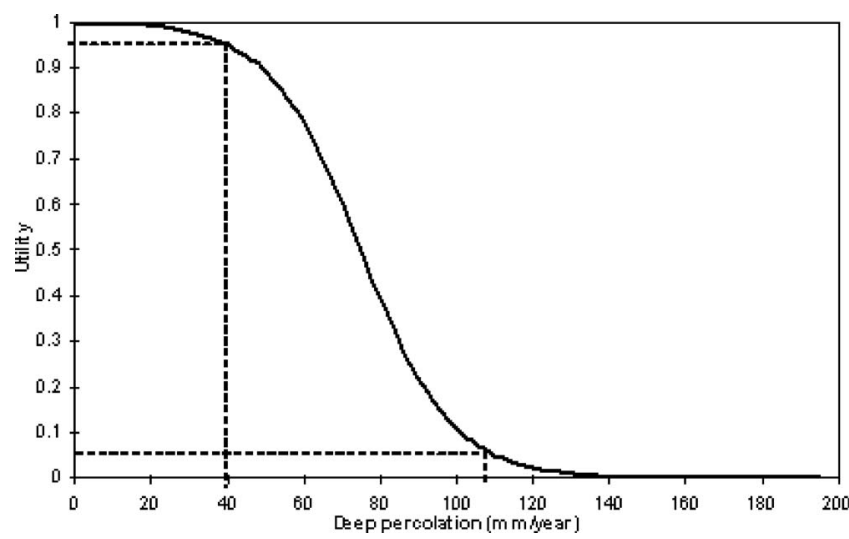

Fig. 9. Logistic utility function relative to deep percolation where $x_{a}=40 \mathrm{~mm}$ and $x_{b}=110 \mathrm{~mm}$, and $U\left(x_{a}\right)=0.95$ and $U\left(x_{b}\right)=0.05$

2. Environmental criteria relative to the potential degradation of groundwater and surface waters and the reduction of nonbeneficial water uses relative to tail-end runoff and deep percolation, potential erosion due to irrigation water flowing over the soil surface, and soil degradation due to land leveling cuts. Hydraulic criteria are represented in the environmental criteria through controlling runoff and percolation.

The attributes are scaled according to a measure of utility using value or utility functions, which are applied to the environmental and economic criteria. This approach enables us to compare variables having different units, which is one of the primary benefits of the multicriteria methodology. With this procedure, the utilities $U_{j}$ for any criterion $j$ are normalized into the [0-1] interval (zero for the more adverse and 1 for the most advantageous result).

The following linear utility function is applied for the economic criteria:

$$
U_{j}\left(x_{j}\right)=\alpha \cdot x_{j}+\beta
$$

where $x_{j}=$ attribute; $\alpha=$ graph slope, negative for costs and positive for benefits; and parameter $\beta=$ utility value $U_{j}\left(x_{j}\right)$ for a null value of the attribute. A logistic utility function (Fig. 9) is adopted for the environmental criteria

$$
U_{j}\left(x_{j}\right)=\frac{e^{K_{\mathrm{bj}}\left(x_{\mathrm{Mj}}-x_{j}\right)}}{e^{K_{\mathrm{aj}}+e^{K_{\mathrm{bj}}\left(x_{\mathrm{Mj}}-x_{j}\right)}}}
$$

where $K_{\mathrm{aj}}$ and $K_{\mathrm{bj}}=$ function parameters; and $x_{\mathrm{Mj}}=$ maximum attribute value corresponding to a null utility for the $j$ criterion. To adjust this function to user preferences, it is necessary to select the attribute values $x_{a}$ and $x_{b}$ that correspond to a very low and a very significant impact, e.g., such that $U\left(x_{a}\right)=0.95$ and $U\left(x_{b}\right)$ $=0.05$, as shown in Fig. 9. Based on these values, and for a specific criterion, the parameters $K_{a}$ and $K_{b}$ are then calculated as follows (Janssen 1992):

$$
\begin{gathered}
K_{a}=\ln \left[\frac{\left(1-U\left(x_{a}\right)\right) \cdot e^{K_{b} \cdot\left(\alpha_{M}-x_{a}\right)}}{U\left(x_{a}\right)}\right] \\
K_{b}=\frac{\ln \left[\frac{U\left(x_{a}\right) \cdot\left(1-U\left(x_{b}\right)\right)}{\left(1-U\left(x_{a}\right)\right) \cdot U\left(x_{b}\right)}\right]}{x_{b}-x_{a}}
\end{gathered}
$$

The dominance preanalysis is a procedure to select the nondominated alternatives. For these alternatives do not exist any other feasible alternative that could improve the performance relative to any criterion without decreasing the performance of any other criterion. The multicriteria selection applies to those nondominated alternatives. The satisfaction preanalysis screens the alternatives set by selecting the user acceptable ones, i.e., those that for every criterion perform better than a minimum level required by the decision maker.

To apply the multicriteria methods, the user needs to assign priorities by selecting the weights $\lambda_{j}$ that represent the relative importance of each criterion $j$ as viewed by the decision maker. These can be directly defined by the decision maker or calculated by the Analytical hierarchy Process (AHP) method (Saaty 1990).

Two multicriteria methods may be applied: the composite programming (Bogardi and Bardossy 1983) and the ELECTRE II (Roy and Bouyssou 1993; Roy 1996). The composite programming is an aggregative multicriteria method that leads to a unique global criterion. It is a distance-based technique designed to identify the alternative closest to an ideal solution using a quasi-distance measure. This method allows the analysis of a multidimensional selection problem by a partial representation in a two dimension trade-off surface (e.g., Figs. 12 and 13, which are explained later in more detail).

The distance to the ideal point $\left(L_{j}=1-U_{j}\right)$ relative to each alternative $a_{k}$, is a performance measure of $a_{k}$ according to the criterion $j$. The ideal point represents the point on the trade-off surface where an irrigation design would be placed if the criteria under consideration were at their best possible level. If this distance is short, this performance is near the optimum. The composite distance $L$ is computed for each set of $N$ criteria as

$$
L=\left[\sum_{j=1}^{N} \lambda_{j} \cdot L_{j}^{p}\right]^{1 / p}
$$

where $L_{j}=$ distance to the ideal point relative to criterion $j$; and $p=$ balancing factor between criteria. Each composite distance corresponds to a distance-based average, arithmetic or geometric, respectively, when $p=1$ or $p=2$. The balancing factor $p$ indicates the importance of the maximal deviations of the criteria and limits the ability of one criterion to be substituted by another. A high balancing factor gives more importance to large negative impacts (a larger distance to the ideal point) relative to any criterion, rather than allowing these impacts to be obscured by the trade-off process.

The ELECTRE II is an outranking method that aims to rank alternatives. It is based on the dominance relationship for each pair of alternatives, which is calculated from the concordance and discordance indices. The concordance represents the degree to which an alternative $k$ is better than another alternative $m$. A concordance index is then defined as the sum of weights of the criteria included in the concordance set relative to the criteria for which the alternative $k$ is at least equally attractive as the alternative $m$. The discordance reflects the degree to which an alternative $k$ is worse than alternative $m$. For each criterion from a discordance set, that includes the criteria for which alternative $k$ is worse than $m$, the differences between the scores of $k$ and $m$ are calculated. The discordance index, defined as the largest of these differences, reflects the idea that, beyond a certain level, bad performances on one criterion cannot be compensated by a good performance relative to another criterion. The decision maker indicates the thresholds that are used to establish a weak and a strong outranking relationship between each pair of alternatives.

For every project of a given field (Fig. 5), SADREG produces a large set of alternatives as a result of numerous combinations of design and operation variables. As mentioned before, these alter- 
Table 6. Alternatives Selected Using Composite Programming for Several Land Parcels and Soil Types in Tentúgal Sector

\begin{tabular}{|c|c|c|c|c|}
\hline $\begin{array}{l}\text { Field size }{ }^{\mathrm{a}} \\
(*)\end{array}$ & Sandy soil & Sandy loam soil & Loam soil & Silty loam soil \\
\hline $100 \times 75$ & $\begin{array}{l}\text {-GF, } S_{y}=0.20 \text {, diked } \\
\text {-GF, } S_{y}=0.20 \text {, reuse } \\
\text {-GF, } S_{y}=0.10 \text {, diked }\end{array}$ & $\begin{array}{l}\text {-GF, } S_{y}=0.10 \text {, diked } \\
\text {-GF, } S_{y}=0.05 \text {, diked } \\
\text {-LB (furrowed) }\end{array}$ & $\begin{array}{l}\text {-GF, } S_{y}=0.05 \text {, diked } \\
\text {-GB, } S_{y}=0.05 \text {, diked } \\
\text {-LB (furrowed) }\end{array}$ & $\begin{array}{l}\text {-LB (furrowed) } \\
\text {-GF, } S_{y}=0.05 \text {, diked } \\
\text {-GF, } S_{y}=0.05 \text {, reuse }\end{array}$ \\
\hline $150 \times 75$ & $\begin{array}{l}\text {-GF, } S_{y}=0.20, \text { diked } \\
\text {-GF, } S_{y}=0.20 \text {, open } \\
\text {-GF, } S_{y}=0.30 \text {, diked }\end{array}$ & $\begin{array}{l}\text {-GF, } S_{y}=0.10 \text {, diked } \\
\text {-GF, } S_{y}=0.20 \text {, diked } \\
\text {-GF, } S_{y}=0.05 \text {, diked }\end{array}$ & $\begin{array}{l}\text {-GF, } S_{y}=0.10, \text { diked } \\
\text {-GF, } S_{y}=0.05 \text {, diked } \\
\text {-GF, } S_{y}=0.05, \text { reuse }\end{array}$ & $\begin{array}{l}\text {-GF, } S_{y}=0.05 \text {, diked } \\
\text {-LB (furrowed) } \\
\text {-GB, } S_{y}=0.05 \text {, diked }\end{array}$ \\
\hline $200 \times 125$ & -no acceptable alternatives were made & $\begin{array}{l}\text {-GF, } S_{y}=0.20 \text {, diked } \\
\text {-GF, } S_{y}=0.05 \text {, diked } \\
\text {-GF, } S_{y}=0.10, \text { diked }\end{array}$ & $\begin{array}{l}\text {-GF, } S_{y}=0.10, \text { diked } \\
\text {-GF, } S_{y}=0.05 \text {, diked } \\
\text {-GF, } S_{y}=0.05, \text { reuse }\end{array}$ & $\begin{array}{l}\text {-GF, } S_{y}=0.05 \text {, diked } \\
\text {-LB (furrowed) } \\
\text {-GB, } S_{y}=0.05 \text {, diked }\end{array}$ \\
\hline $265 \times 75$ & -no acceptable alternatives were made & $\begin{array}{l}\text {-GF, } S_{y}=0.10, \text { diked } \\
\text {-GF, } S_{y}=0.05 \text {, diked } \\
\text {-GF, } S_{y}=0.05, \text { open }\end{array}$ & $\begin{array}{l}\text {-GF, } S_{y}=0.05, \text { diked } \\
\text {-GF, } S_{y}=0.10, \text { diked } \\
\text {-GF, } S_{y}=0.05, \text { reuse }\end{array}$ & $\begin{array}{l}\text {-GF, } S_{y}=0.05, \text { diked } \\
\text {-GF, } S_{y}=0.05 \text {, reuse } \\
\text {-GB, } S_{y}=0.05, \text { reuse }\end{array}$ \\
\hline $200 \times 340$ & -no acceptable alternatives were made & $\begin{array}{l}\text {-GF, } S_{y}=0.20, \text { reuse } \\
\text {-GF, } S_{y}=0.20, \text { open } \\
\text {-GF, } S_{y}=0.20, \text { diked }\end{array}$ & $\begin{array}{l}\text {-GF, } S_{y}=0.05 \text {, diked } \\
\text {-GF, } S_{y}=0.05, \text { open } \\
\text {-GF, } S_{y}=0.05, \text { reuse }\end{array}$ & $\begin{array}{l}\text {-GF, } S_{y}=0.05 \text {, diked } \\
\text {-LB (furrowed) } \\
\text {-GB, } S_{y}=0.05 \text {, diked }\end{array}$ \\
\hline
\end{tabular}

Note: $\mathrm{GB}=$ graded border; GF= graded furrows; $\mathrm{LB}=$ level basin; $S_{y}=$ longitudinal slope $(\%)$.

${ }^{\mathrm{a}}$ Field length $\times$ field width $(\mathrm{m})$.

natives are clustered by groups relative to different water distribution equipment and tail end management options. The multicriteria analysis allows the alternative selection for each group and the ranking and comparison of the groups of a given project. This analysis plays an important role on the automatic management of a large amount of data, screening the alternatives, removing those not satisfactory or dominated, and ranking and selecting the most adequate according to the user priorities.

\section{Application}

To illustrate the application of multicriteria analysis for surface irrigation design, an application of the DSS SADREG to the sector of Tentúgal of the Lower Mondego Irrigation System, Portugal, is presented. This application provided for the evaluation and selection of irrigation methods and water supply systems to be adopted in various farm fields (Gonçalves and Pereira 1999). The weights were selected in such a way that priorities assigned to water saving, minimizing costs, and maximizing benefits were balanced.

\section{Best Alternatives to Various Parcels and Soil Types}

The alternative solutions selected after the application of the composite programming method are listed in Table 6. Results have shown that the preference for a method is related to the size of the field and to the intake rate of the soil, which is a variable of fundamental importance. However, results were not conclusive concerning the tail end systems. The environmental criteria played an important role in the discrimination among alternatives.

This multicriteria approach was applied to a number of fields having different characteristics, mainly concerning the area. Thus, a large amount of data was handled through the DSS, which could provide for more detailed analysis. As an example, an analysis of the economic impacts of various farm water distribution systems in relation to the field area is presented. It refers to the comparison of total costs of a PVC gated pipe (GP) system with other systems-PVC gated pipes with surge-flow valves (GP-SF), layflat tubing (LF), and unlined farm canal with siphons (CS) (Fig. 10). The analysis shows that adopting surge flow for small fields highly increases the costs relative to continuous flow using GP. The difference between GP and GP-SF costs decreases when the field size increases, becoming quite small for areas larger than 2 ha. LF and CS systems are less expensive than GP; differences in costs among all three systems are generally small, mainly up to 2 ha field area.

When the same water distribution systems are compared relative to the share of O\&M costs in the total costs, it becomes apparent that surge flow automation (GP-SF) is the one where $\mathrm{O} \& \mathrm{M}$ costs are smaller and $\mathrm{CS}$ is the one having larger O\&M costs (Fig. 11). The influence of field size is also important. Assigning to O\&M costs a weight higher than for investment costs favors adopting systems requiring less labor and more equipment, mainly if equipment is used in other fields, thus, decreasing the respective investment. Contrarily, for small farms, results indicate that adopting water distribution systems requiring less investment and higher labor could be preferable. When ranking alternatives, various factors may be considered to select weights. Giving higher weights to environmental criteria and lower weights to costs may favor the adoption of more expensive water distribution systems.

\section{Selection of the Best Alternative to a Single Field}

The application example presented herein refers to a field with $200 \mathrm{~m}$ length and $100 \mathrm{~m}$ width, and a longitudinal slope of $0.10 \%$. Composite programming and the ELECTRE II methods are applied.

Fig. 12 shows the output from the composite programming application to rank the alternatives relative to the economic and environmental criteria. The curves drawn are isodistance lines to the ideal point. Results indicate that the best alternatives are $a$ to $j$, which show the same global score. Applying the trade-off analysis to analyze the impacts in terms of soil conservation and potential for water contamination (Fig. 13) allows identifying $a$, $b$, and $\mathrm{c}$ as the best alternatives. This partial analysis shown in Fig. 13 is an advantage of composite programming, because it allows a better evaluation of characteristics that differentiate the alternatives.

Fig. 14 shows the outranking graph produced through the application of the ELECTRE II method. The solid line arrows rep- 


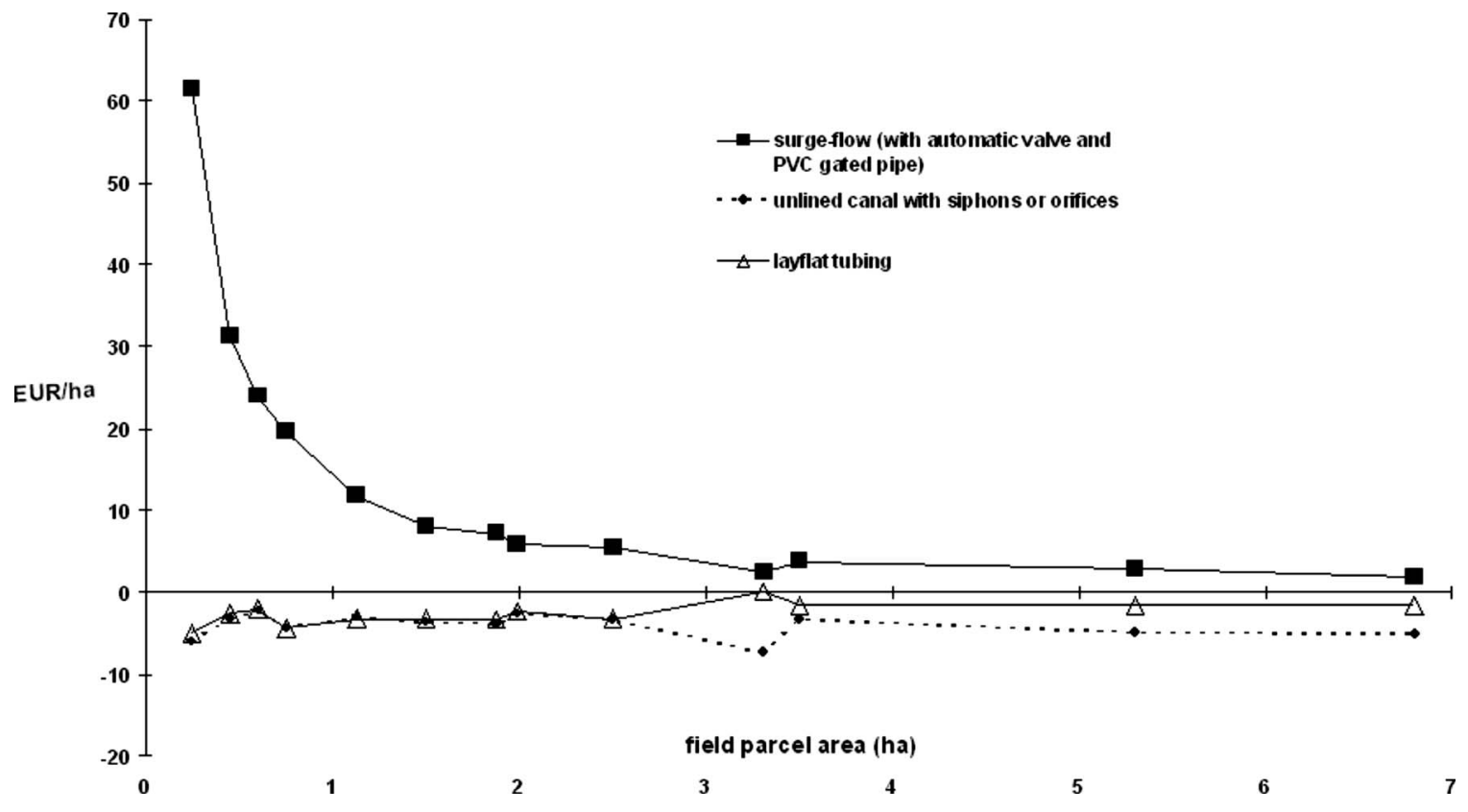

Fig. 10. Differences in costs (EUR/ha/year) between a PVC gated pipe system and an unlined field canal, layflat tubing and a gated pipe with an automatic surge-flow valve as a function of the field area

resent the strong outranking between each pair of alternatives. From this outranking (according to the direction of the arrows), the alternatives $c, d, g, j, m$, and $o$ were selected. This set of alternatives is named graph's kernel. Within the graph's kernel a weak outranking is established, represented by the dashed arrows. From the respective analysis it could be concluded that the best alternatives are $c$ and $g$, followed by $d, j, m$, and $o$.

It is important to note that by adopting both the ELECTRE II and the composite programming methods, it became easier to select the best alternative $c$ in this application.

\section{Conclusions}

Appropriate design of surface irrigation systems requires a complex manipulation of data, models, and decisions. The multicriteria approach integrated in a DSS enables us to solve that complexity while creating and ranking a large number of design alternatives. The DSS SADREG has shown to be an appropriate tool for (1) generating design alternatives associated with attributes of technical, economic, and environmental nature; (2) handling and evaluating a large number of input and output data;

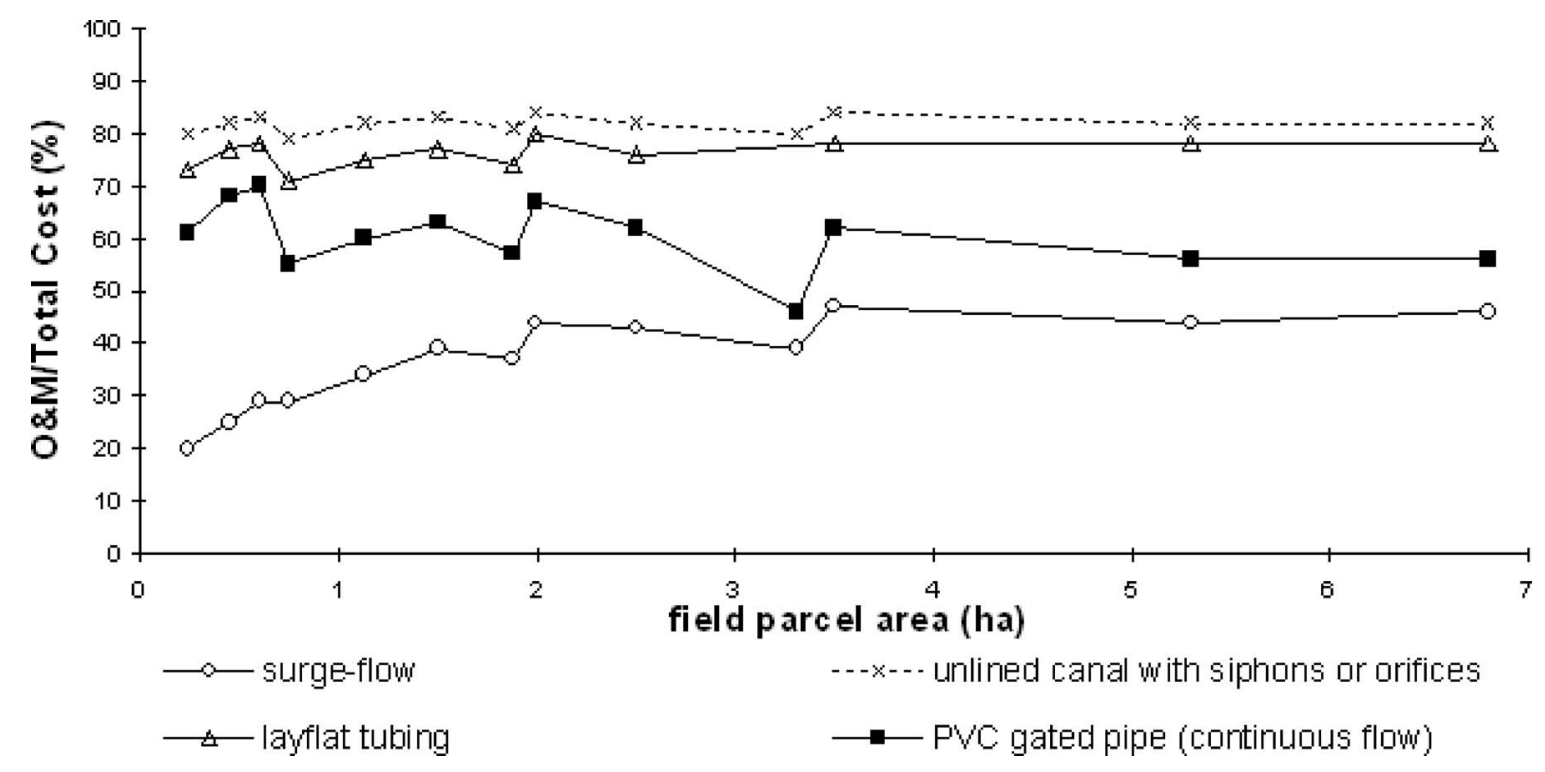

Fig. 11. Ratio of O\&M costs to total annual costs for several farm water distribution systems as a function of the field area 


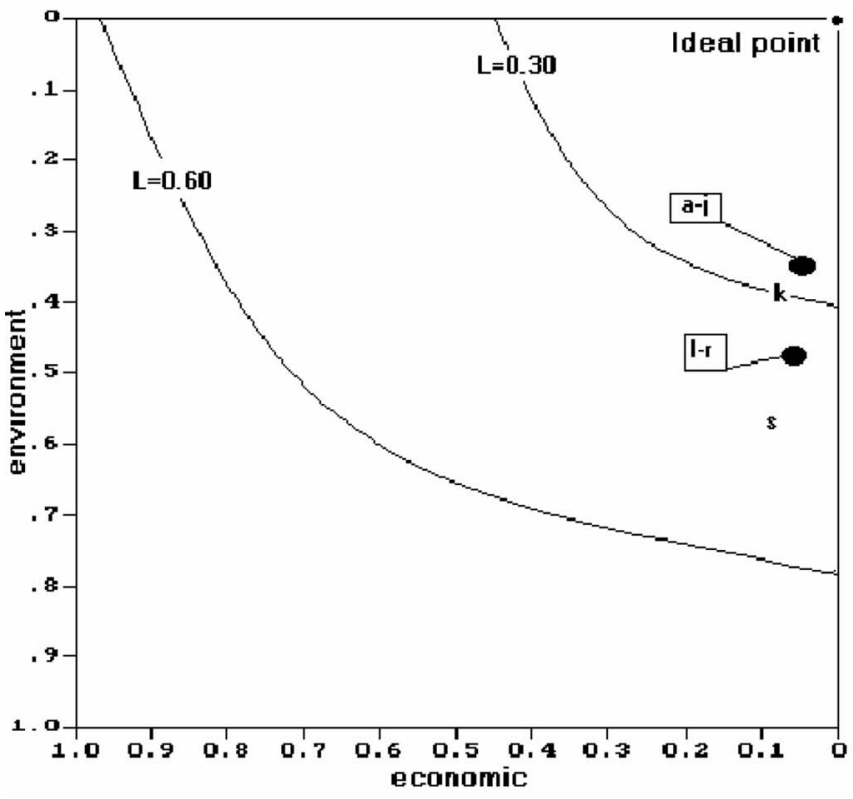

LEGEND

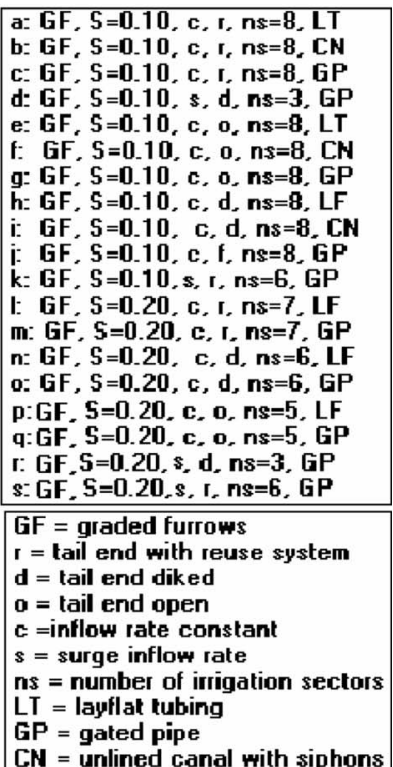

Fig. 12. Isodistance lines when ranking alternatives through composite programming and performing a trade-off analysis among economic and environmental impacts; the best alternatives are $a$ to $j$

(3) evaluating and ranking design alternatives using multicriteria analysis where criteria are weighted according to the priorities and perception of the designer and users; and (4) providing an appropriate dialogue between the designer and the user.

The application of the DSS to the case study presented herein shows the advantage in adopting two multicriteria analysis models, the composite programming and ELECTRE II, that when used together allow us to find more rationally the best solution. The application also shows that selecting weights for assigning priorities requires appropriate knowledge of factors influencing the ranking, which may imply learning by doing. As for any simu- lation model, the quality of results not only depends upon the quality of the models but also on the quality of data, particularly field data. Further developments relative to different case studies refer to the GIS linkages for handling data at the sector level, and exploring outputs in the perspectives of enhancing water saving and water productivity.

\section{Acknowledgments}

The support granted by the Agricultural Engineering Research Centre, Lisbon, is acknowledged.

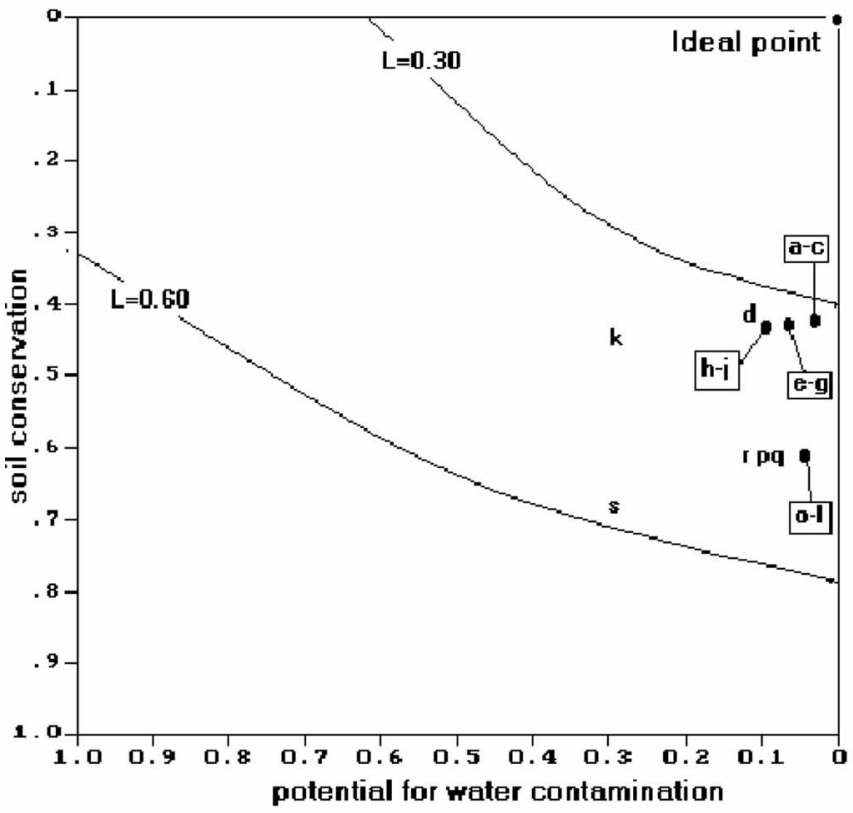

LEGEND

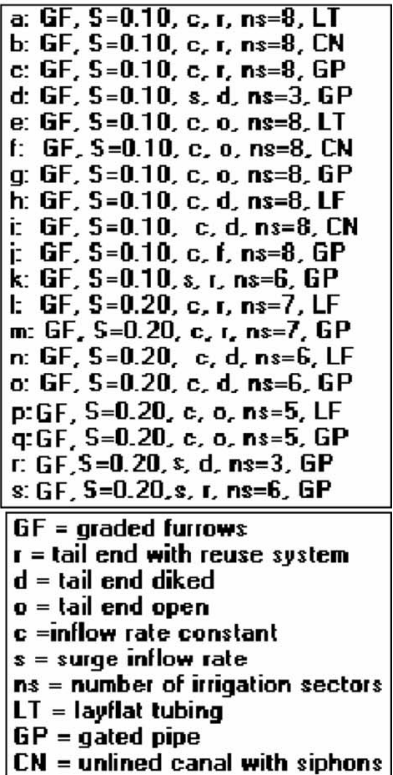

Fig. 13. Isodistance lines when ranking alternatives through composite programming and performing a trade-off analysis relative to impacts on soil conservation and potential for water contamination following the application in Fig. 12; the best alternatives are $a$ to $c$ 


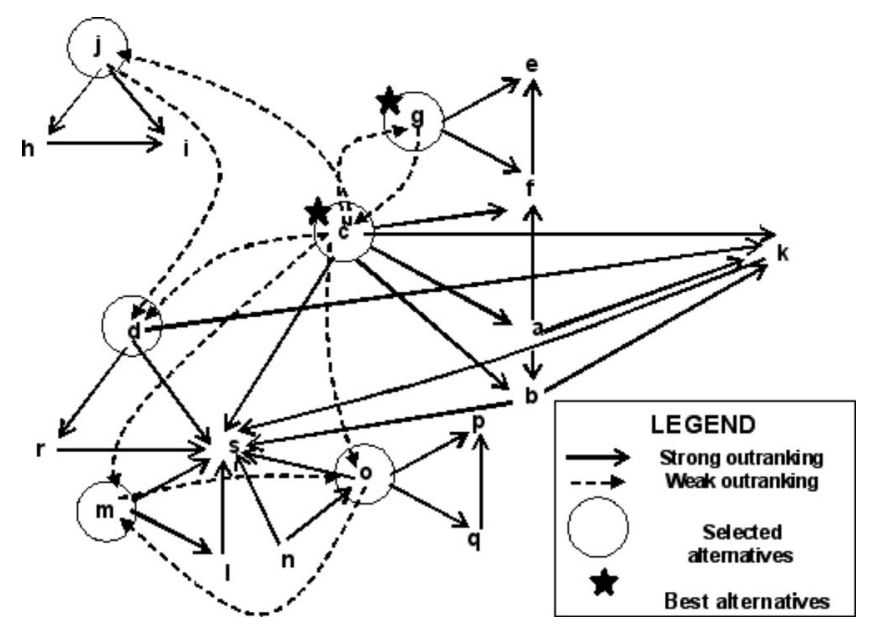

Fig. 14. Example of an outranking graph relative to the application of the ELECTRE II method to rank the alternatives (the same as in Figs. 12 and 13) showing strong and weak outranking among every pair of alternatives according to the arrow directions; the strong outranking allows the identification of the best set of alternatives $(c, d, g, j, m, o)$, and the weak outranking among them permits the final selection of the best alternatives, $c$ and $g$

\section{Appendix. Cost Analysis Equations}

Investment costs (IC\$):

Formulas

Units

$\mathrm{IC}_{\mathrm{va}}$-Present worth cost of one given component

$\mathrm{IC}_{\mathrm{va}}=\mathrm{IC} \cdot\left(1+\left[\sum_{j=1}^{N_{\mathrm{sub}}}\left(\frac{1}{1+i_{\mathrm{TA}}}\right)^{j \cdot N_{\mathrm{LT}}}\right]\right)$

CRF—capital recovery factor

$\mathrm{CRF}=\frac{i_{\mathrm{TA}} \cdot\left(1+i_{\mathrm{TA}}\right)^{N_{\mathrm{AP}}}}{\left(1+i_{\mathrm{TA}}\right)^{N_{\mathrm{AP}}}-1}$

AFC-Annual fixed cost

$\mathrm{AFC}=\mathrm{CRF} \cdot \sum_{j=1}^{N_{\text {comp }} \mathrm{IC}_{\mathrm{va}_{j}}}$

$€ /$ year

$\mathrm{IC}_{\mathrm{LL}}$-initial leveling cost

$\mathrm{IC}_{\mathrm{LL}}=a_{0}+a_{1} \cdot t_{\mathrm{mac}}$

$€$

$t_{\mathrm{mac}}$ - time of machine operation required for land

$t_{\text {mac }}=t_{\text {uexc }} \cdot V_{\text {exc }}$ or $t_{\text {mac }}=t_{\text {uarea }} \cdot A$

$\mathrm{h}$

leveling

$\mathrm{IC}_{D}$-distribution system cost

$\mathrm{IC}_{D}=b_{0}+b_{1} \cdot \mathrm{FW}$

$€$

$\mathrm{IC}_{R}$-reuse system cost

$\mathrm{IC}_{R}=r_{0}+r_{1} \cdot A$

$€$

$\mathrm{IC}_{T}$-total investment annual cost

$\mathrm{IC}_{T}=\mathrm{IC}_{\mathrm{LL}}+\mathrm{IC}_{D}+\mathrm{IC}_{R}$

$€ /$ year

Operation and maintenance costs (OMC\$):

$\mathrm{OMC}_{R}$ - Reuse pumping system cost

$\mathrm{OMC}_{R}=r_{2} \cdot \mathrm{VR}$

$€ /$ year

$\mathrm{OMC}_{\mathrm{LL}}$ - Land leveling maintenance cost

$\mathrm{OMC}_{\mathrm{LL}}=a_{0}+a_{1} \cdot a_{2} \cdot A$

$€ /$ year

$\mathrm{OMC}_{D}=h, 0 \cdot t_{\mathrm{Mt}}$

$€ /$ year

$t_{\text {Minst }}-$ Man power time to install the distribution

$t_{\text {Minst }}=h_{1} \cdot \mathrm{FW}$

h/year system

$t_{\mathrm{Mrem}}=h_{2} \cdot \mathrm{FW}$

h/year

$t_{\text {Mrem }}-$
system

$t_{\text {Mope }}=h_{3} \cdot S_{U} W$

$\mathrm{h}$

$t_{\text {Mope }}$-Effective man power time to operate a subunit

$t_{\text {Mfree }}=t_{\text {ap }}-t_{\text {Mope }}$

$\min$

$t_{\text {Mfree }}$-Free man power time in a subunit irrigation

$t_{\mathrm{MopU}}=t_{\mathrm{MopSU}} \cdot \mathrm{ns}, \ldots$ if $t_{\mathrm{Mfree}}>t_{\mathrm{Mmin}}$

$\mathrm{h}$

$t_{\mathrm{Mt}}$ - Total man power time required by the

$t_{\mathrm{MopU}}=t_{\mathrm{ap}} \cdot \mathrm{ns}, \ldots$ if $t_{\mathrm{Mfree}} \leq t_{\mathrm{Mmin}}$

$t_{\mathrm{Mt}}=t_{\text {Minst }}+\sum_{j=1}^{N \text { irrig }}\left(N_{u} \times t_{\text {MopU }}\right)$

h/year

distribution system

$\mathrm{OMC}_{T}=\mathrm{OMC}_{\mathrm{LL}}+\mathrm{OMC}_{D}+\mathrm{OMC}_{R}$

$€ /$ year 


\section{Notation}

The following symbols are used in this paper:

$A=$ field area (ha);

$a_{0}=$ leveling machines fixed cost (€/operation);

$a_{1}=$ hourly cost of the land leveling machines $(€ / \mathrm{h})$;

$a_{2}=$ unitary maintenance leveling machine time (h/ha);

$b_{0}=$ distribution system fixed cost (for example, valves) (€);

$b_{1}=$ unitary distribution system cost $(€ / m)$;

$\mathrm{FL}=$ field length $(\mathrm{m})$;

$\mathrm{FW}=$ field width $(\mathrm{m})$;

$h_{0}=$ hourly cost of the man power $(€ / \mathrm{h})$;

$h_{1}=$ unitary man power time to install the distribution system $(\mathrm{h} / \mathrm{m})$;

$h_{2}=$ unitary man power time to remove distribution system $(\mathrm{h} / \mathrm{m})$;

$h_{3}=$ unitary man power time to operate the distribution system $(\mathrm{h} / \mathrm{m})$;

$\mathrm{IC}=$ investment costs;

$i_{\mathrm{TA}}=$ annual interest rate (decimal);

$N_{\mathrm{AP}}=$ analysis period (years);

$N_{\text {comp }}=$ number of equipment components;

$N_{\text {irrig }}=$ annual number of irrigation events;

$N_{\mathrm{LT}}=$ equipment component life time (years);

$N_{\text {sub }}=$ number of component replacements during period analysis;

$N_{u}=$ number of units per field;

$\mathrm{ns}=$ number of subunits per unit;

$r_{0}=$ reuse system fixed cost $(€)$;

$r_{1}=$ unitary reuse system cost (€/ha);

$r_{2}=$ unitary reuse system variable cost $\left(€ / \mathrm{m}^{3}\right)$;

$S_{U} W=$ subunit width $(\mathrm{m})$;

$t_{\text {ap }}=$ application time ( $\left.\min \right)$;

$t_{\mathrm{Mmin}}=$ additional time required to other tasks relative to irrigation ( $\mathrm{min})$; it is the minimum time period between subunit operation (closed and open irrigation set) that allows irrigation man power to be allocated to other tasks;

$t_{\text {uarea }}=$ unitary machinery time required to land smoothing (h/ha)

$t_{\text {uexc }}=$ unitary machinery for cut volume $\left(\mathrm{h} / \mathrm{m}^{3}\right)$;

$V_{\text {exc }}=$ land leveling excavation volume $\left(\mathrm{m}^{3}\right)$; and

$\mathrm{VR}=$ pumping reuse volume $\left(\mathrm{m}^{3} /\right.$ year $)$

\section{References}

Bazzani, G. M. (2005). "An integrated decision support system for irrigation and water policy design: DSIRR." Environ. Modell. Software, 20(2), 153-163.

Bogardi, I., and Bardossy, A. (1983). "Application of MCDM to geological exploration." Essays and surveys on multiple criteria decision making, P. Hansen, ed., Springer Verlag, New York.

Boonstra, J., and Jurriens, M. (1978). "BASCAD—A mathematical model for level basin irrigation." ILRI Publication No. 43, Wageningen.

Burt, C. M., et al. (1997). "Irrigation performance measures: Efficiency and uniformity." J. Irrig. Drain. Eng., 123, 423-442.

Camacho, E., Pérez, C., Roldán, J., and Alcalde, M. (1997). "IPE: Model for management and control of furrow irrigation in real time." J. Irrig. Drain. Eng., 123(4), 264-269.

Clemmens, A. J. (1979). "Verification of the zero-inertia model for border-irrigation advance." J. Irrig. and Drain. Div., 104(3), 339341.

Clemmens, A. J. (2007). "Simple approach to surface irrigation design: Theory." e-Journal of Land and Water, 1, 1-19, 〈http:// www.sakia.org/ejlw $\rangle$.

Clemmens, A. J., Dedrick, A. R., and Strand, R. (1993). "BASIN 2.0 for the design of level-basin systems." Management of irrigation and drainage systems, R. G. Allen, ed., ASCE, New York, 875-882.

Criddle, W. D., Davis, S., Pair, C., and Shockley, D. (1956). Methods for evaluating irrigation systems, USDA SCS Agricultural Handbook No. 82.

Dedrick, A. R., Gaddis, R. J., Clark, A. W., and Moore, A. W. (2007). "Land forming for irrigation." Design and operation of farm irrigation systems, 2nd Ed., G. J. Hoffman, R. G. Evans, M. E. Jensen, D. L. Martin, and R. L. Elliot, eds., ASABE, St. Joseph, Mich., 320-346.

Elliott, R. L., Walker, W. R., and Skogerboe, G. V. (1982). "Zero inertia modeling of furrow irrigation advance." J. Irrig. and Drain. Div., 108(3), 179-195.

Fangemeier, D. D., and Strelkoff, T. (1978). "Mathematical models and border irrigation design." Trans. ASAE, 22(1), 93-99.

Gonçalves, J. M., and Pereira, L. S. (1999). "Design of sustainable onfarm surface irrigation systems with a decision support system." Emerging technologies for sustainable land use and water management (CD-ROM), A. Musy, L. S. Pereira, and M. Fritsch, eds., Presses Polytechniques et Universitaires Romandes, Lausanne, Switzerland, Paper 8.10.

Gonçalves, J. M., Pereira, L. S., Fang, S. X., and Dong, B. (2007). "Modelling and multicriteria analysis of water saving scenarios for an irrigation district in the Upper Yellow River Basin." Agric. Water Manage., 94(1-3), 93-108.

Hart, W. E., Collins, H. G., Woodward, G., and Humpherys, A. S. (1980). "Design and operation of gravity or surface systems." Design and operation of farm irrigation systems, M. E. Jensen, ed., ASAE Monograph No. 3, St. Joseph, Mich., 501-580.

Hornbuckle, J. W., Christen, E. W., and Faulkner, R. D. (2005). "Use of SIRMOD as a quasi-real time surface irrigation decision support system." A. Zerger, and R. M. Argent, eds., Proc., MODSIM 2005 Int. Congress on Modelling and Simulation, by Modeling and Simulation Society of Australia and New Zealand, December 2005, 217-223, 〈http://www.mssanz.org.au/modsim05/papers/hornbuckle_1.pdf〉,

Horst, M. G., Shamutalov, S. S., Gonçalves, J. M., and Pereira, L. S. (2007). "Assessing impacts of surge-flow irrigation on water saving and productivity of cotton." Agric. Water Manage., 87, 115-127.

Janssen, R. (1992). Multiobjective decision support for environmental management, Kluwer, Dordrecht, The Netherlands.

Latimer, E. A., and Reddel, D. L. (1990). "A volume balance model for real time automated furrow irrigation system." Visions of the futureTechnology to enrich our environment, ASAE, St. Joseph, Mich., 1320.

Mailhol, J. C., Ruelle, P., and Popova, Z. (2005). "Simulation of furrow irrigation practices (SOFIP): A field-scale modelling of water management and crop yield for furrow irrigation." Interfaces, 24(1), 37-48.

McClymont, D. (1999). "FIDO v2: Furrow irrigation design optimiser." Proc., Multiple Objective Decision Support Systems Conf., 〈http:// www.ncea.org.au/www/Irrigation/FIDO/Project_FIDO.htm $\rangle$.

Mjeld, J. W., Lacewell, R. D., Talpaz, H., and Taylor, C. R. (1990). "Economics of irrigation systems." Management of farm irrigation systems, G. F. Hoffman, T. A. Howell, and K. H. Solomon, eds., ASAE, St. Joseph, Mich., 461-493.

Oad, R., Garcia, L., Kinzli, K. D., and Patterson, D. (2006). "Decision support systems for efficient irrigated agriculture." WIT transactions on ecology and the environment, Vol. 96, G. Lorenzini, and C. A. Brebbia, eds., WIT Press, Wessex, U.K., 247-256.

Oweis, T. Y., and Walker, W. R. (1990). "Zero-inertia model for surge flow furrow irrigation." Irrig. Sci., 11(3), 131-136.

Pereira, L. S. (1999). "Higher performances through combined improvements in irrigation methods and scheduling: A discussion." Agric. 
Water Manage., 40(2-3), 153-169.

Pereira, L. S., Oweis, T., and Zairi, A. (2002). "Irrigation management under water scarcity." Agric. Water Manage., 57, 175-206.

Pereira, L. S., Teodoro, P. R., Rodrigues, P. N., and Teixeira, J. L. (2003). "Irrigation scheduling simulation: The model ISAREG." Tools for drought mitigation in mediterranean regions. G. Rossi, A. Cancelliere, L. S. Pereira, T. Oweis, M. Shatanawi, and A. Zairi, eds., Kluwer, Dordrecht, The Netherlands, 161-180.

Pereira, L. S., and Trout, T. J. (1999). "Irrigation methods." CIGR handbook of agricultural engineering, land and water engineering, Vol. I. H. N. van Lier, L. S. Pereira, and F. R. Steiner, eds., ASAE, St. Joseph, Mich., 297-379.

Pereira, L. S., Zairi, A., and Mailhol, J. C. (2006). "Irrigation de surface." Traité d'irrigation, 2nd Ed., J. R. Tiercelin and A. Vidal, eds., Lavoisier, Paris, 513-549.

Pomerol, J. C., and Romero, S. B. (2000). Multicriterion decision in management: Principles and practice, Kluwer Dordrecht, The Netherlands.

Raju, K. S., and Duckstein, L. (2002). "Multicriterion analysis for ranking an irrigation system: An Indian case study." J. Decision Systems, 11, 499-511.

Raju, K. S., Kumar, D. N., and Duckstein, L. (2006). "Artificial neural networks and multicriterion analysis for sustainable irrigation planning." Comput. Oper. Res., 33(4), 1138-1153.

Rao, N. H., Brownee, S. M., and Sarma, P. B. (2004). "GIS-based decision support system for real time water demand estimation in canal irrigation systems." Curr. Sci. India, 87, 5-10.

Reddy, J. M., and Clyma, W. (1981a). "Optimal design of border irrigation system.” J. Irrig. and Drain. Div., 17(3), 289-306.

Reddy, J. M., and Clyma, W. (1981b). "Optimal design of furrow irrigation systems." Trans. ASAE, 24(3), 617-623.

Riesgo, L., and Gómez-Limón, J. A. (2006). "Multi-criteria policy scenario analysis for public regulation of irrigated agriculture." Agric. Systems, 91, 1-28.

Roy, B. (1996). Multicriteria methodology for decision aiding, Kluwer, Dordrecht, The Netherlands.

Roy, B., and Bouyssou, D. (1993). Aide multicritère: Méthodes et cas, Economica, Paris.

Saaty, T. L. (1990). "How to make a decision: the AHP." Eur. J. Oper. Res., 48(1), 9-26.

Soil Conservation Service (SCS). (1974). "Chapt. 4, Border Irrigation."
Soil conservation service national engineering handbook. Sect. 15, Irrigation, USDA Soil Conservation Service, Washington, D.C.

Soil Conservation Service (SCS). (1979). "Chap.5, Furrow Irrigation." Soil conservation service national engineering handbook, Sect. 15, Irrigation, USDA Soil Conservation Service, Washington, D.C.

Solomon, K. H. (1984). "Yield related interpretations of irrigation uniformity and efficiency measures." Irrig. Sci., 5(3), 161-172.

Solomon, K. H., El-Gindy, A. M., and Ibatullin, S. R. (2007). "Planning and system selection." Design and operation of farm irrigation systems, 2nd Ed., G. J. Hoffman, R. G. Evans, M. E. Jensen, D. L. Martin, and R. L. Elliot, eds., ASABE, St. Joseph, Mich., 57-75.

Strelkoff, T. (1990). "SRFR. A computer program for simulating flow in surface irrigation furrows-basins-borders." WC: Rep. 17, U.S. Water Conservation Laboratory, USDA/ARS, Phoenix.

Strelkoff, T., and Clemmens, A. J. (2007). "Hydraulics of surface systems." Design and operation of farm irrigation systems, 2nd Ed., G. J. Hoffman, R. G. Evans, M. E. Jensen, D. L. Martin, and R. L. Elliot, eds., ASABE, St. Joseph, Mich., 436-498.

Strelkoff, T., Clemmens, A. J., Schmidt, B. V., and Slosky, E. J. (1996). "BORDER-A design and management aid for sloping border irrigation systems. Version 1.0." WCL Rep. No. 21. USDA, ARS, USWCL, Phoenix, Ariz.

Strelkoff, T., and Katopodes, N. D. (1977). "Border irrigation with zero inertia." J. Irrig. and Drain. Div., 103(3), 325-342.

Strelkoff, T., and Souza, F. (1984). "Modelling the effect of depth on furrow infiltration." J. Irrig. Drain. Eng., 110(4), 375-387.

Walker, W. R. (1989). "Guidelines for designing and evaluating surface irrigation systems." Irrigation and Drainage Paper No. 45, FAO, Rome, Italy.

Walker, W. R. (1998). "SIRMOD-Surface irrigation modeling software." Utah State Univ., Logan, Utah.

Walker, W. R., and Humpherys, A. S. (1983). "Kinematic-wave furrow irrigation model." J. Irrig. Drain. Eng., 109(4), 377-392.

Walker, W. R., and Skogerboe, G. V. (1987). Surface irrigation: Theory and practice, Prentice-Hall, Englewood Cliffs, N.J.

Wilke, O., and Smerdon, E. T. (1965). "A solution of the irrigation advance problem." J. Irrig. and Drain. Div., 91(3), 23-24.

Yu, F. X., and Singh, V. P. (1989). "Analytical model for border irrigation." J. Irrig. Drain. Eng., 115(6), 982-999.

Yu, F. X., and Singh, V. P. (1990). "Analytical model for furrow irrigation.” J. Irrig. Drain. Eng., 116(2), 154-171. 
Copyright of Journal of Irrigation \& Drainage Engineering is the property of American Society of Civil Engineers and its content may not be copied or emailed to multiple sites or posted to a listserv without the copyright holder's express written permission. However, users may print. download, or email articles for individual use. 
Copyright of Journal of Irrigation \& Drainage Engineering is the property of American Society of Civil Engineers and its content may not be copied or emailed to multiple sites or posted to a listserv without the copyright holder's express written permission. However, users may print. download, or email articles for individual use. 